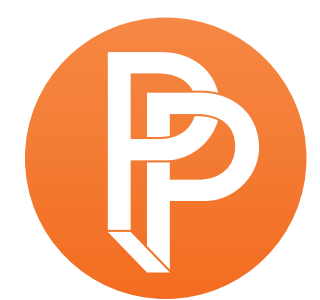

PERFORMANCE

PHILOSOPHY

\title{
PHOTOGRAPHING THE END OF THE WORLD: CAPITALIST TEMPORALITY, CRISIS, AND THE PERFORMATIVITY OF VISUALOBJECTS
}

\author{
ANDREEA S. MICU NORTHWESTERN UNIVERSITY
}

In the fall of 2011, the Greek economic crisis was flooding international media outlets with stories of starved pensioners, debt-induced suicides, and riots in front of the Greek parliament. Meanwhile, a group of photographers named Depression Era were striving to create a different archive of the Greek crisis, avoiding what they considered to be trite media representations that spectacularized poverty and political struggles. The group had started in March, but grew with new additions, eventually bringing together over thirty photographers and video artists. They set off to depict the urban landscape and its peripheries in everyday, ordinary moments, capturing the affects of crisis and austerity.

The Depression Era exhibition opened at the Benaki Museum, in Athens, in November 2014, and was later featured in 5th Thessaloniki Biennale in 2015, and the Athens Biennale 2015-2017. In these spaces, Depression Era's work encountered a variety of audiences, including a majority of Greeks as well as people of other nationalities who visit these art institutions. I came into contact with Depression Era's work in 2015 while on a fieldwork trip to Athens, during which I interviewed several members of the collective. Rather than providing a comprehensive analysis of all the works by Depression Era, for the purpose of this essay, I will focus on four images taken from Marinos Tsagkarakis's series Paradise Inn, Yiannis Hadjiaslanis's series After Dark, Pavlos Fysakis's series Nea Helvetia, and Georges Salameh's series Spleen. These four images depict urban landscapes of abandonment, emptiness, solitude, or quotidian economic collapse. I argue that these images are performative disruptions of capitalist understandings of linear time that capture and foster desires 
for non-capitalist temporalities. I discuss how these works disrupt linear notions of time as progress and measure of productivity and economic growth, which are intrinsic to modernity, debt, and austerity. Against capitalist linear temporality, these Depression Era images enable a realm of visual experimentation in which the spectator is invited to feel time differently, to imagine alternative temporalities that might emerge from a sense of crisis.

Capitalism ${ }^{1}$ cannot function without a linear conception of time. Jean-Luc Nancy (2015) has referred to this capitalist linear temporality as "the equivalence of catastrophes," the compulsory need of our society to rush towards the future even when this future announces itself as catastrophic. For Nancy, this "means to an end" approach defines our political and economic organization, and explains our inability to find a way out of a technological paradigm that leads to destruction. This teleology defines the very idea of modernity and development, and shapes notions of what it is to be fully human as opposed to primitive (Wynter 1996, 2003). It also explains why economic growth is the supreme goal that justifies all forms of sacrifice and violence, such as the ones that austerity demands. Capitalism needs to grow in order to survive. The very structures of credit that uphold its reproduction are based on this linear orientation towards the future (Karatani 2003). A future orientation that is often sustained by promises of wealth that can make present misery bearable for the exploited (Berlant 2011).

This teleology does not only define the reproduction of capital, but also our subjective experience of time. Walter Benjamin ([1940] 2007) defined this as "homogeneous empty time," an eternal present, an accumulation of moments devoid of particular differentiated meanings that could make those moments unique. Benjamin opposes homogeneous empty time to both pre-capitalist notions of time based on cyclical relationships between moments of the past, present, and future, and revolutionary time, which imposes a break in the continuity of linear time. Essential in Benjamin's argument is the link between the linearity of the homogeneous empty time of capitalism and historical progress understood from the perspective of modernity. He states that, "the concept of the historical progress of mankind cannot be sundered from the concept of its progression through a homogeneous, empty time. A critique of the concept of such a progression must be the basis of any criticism of the concept of progress itself" (261).

Benjamin's argument is akin to Antonio Negri's distinction between telos and kairòs (2003). Articulating a critique of the transcendental tradition within Western philosophy, Negri argues that in transcendental philosophy the act of naming-the adequation of name and thing-and therefore the act of knowing is placed outside of time. Thus, time is thought of as an envelope of everything that exists but which does not constitute anything; time is telos, a succession of moments rather than an event, measure rather than creative force. For Negri, the hegemony of this ontology of time suits power, because it empties time from its essential creative potential. Instead, he argues for the need of a materialist philosophical project that thinks time and being as mutually constitutive. For Negri, this time is kairòs, "the instant, that is to say, the quality of the time of the instant, the moment of rupture and opening of temporality" (156). Behind Negri's insistence in the inseparability of name and action, of knowing and doing, lies a fundamental concern: How can a revolutionary subjectivity still exist when capitalist time has subsumed the entirety of life? 
Drawing on these Marxist philosophical approaches to time, I argue that the Depression Era images that I discuss in this essay disrupt capitalist linear temporality and offer audiences other affective explorations of time.

My use of affect throughout this essay attempts to capture the epochal social imaginary that characterizes the Greek crisis beyond its strictly material conditions and which is akin to what Raymond Williams (1977) defined as "structures of feeling". Crisis and austerity loom large in the social imaginaries of Southern Europeans, circulating through images, discourses, and affects. In this sense, the Greek crisis functions not unlike the figural economy of deindustrialization in the American Midwest described by Judith Hamera (2017). Hamera argues that, "even the most seemingly dispassionate discourses of deindustrialization and financialization are partnered by, and circulate within, a field of affect-saturated images, performances, and text that inspire optimistic attachments, industrial nostalgia, and deindustrial melancholy" (14). The same is true about the Greek economic crisis, which is both a set of economic conditions and the societal discourses, images, and feelings that emerge from those conditions. In this sense, we can understand affect as that which "saturates the corporeal, intimate, and political performances of adjustment that make a shared atmosphere something palpable" (Berlant 2011, 16)

My methodological approach to reading these images draws on D. Soyini Madison's discussion of the performative as a "heightened or symbolic act that makes something happen, disturbs, reinvents or creates-large or small-a consequence. In other words, a performative serves as a distinct moment, a punctum or rupture, from the ordinary and familiar that result in a specific causal effect" $(2013,218)$. Drawing on Madison and applying a performance perspective to the analysis of visual objects, Joshua Chambers-Letson has argued that, "photographs are scenes of encounter, whereby the photograph performs for the spectator, creating an affective relationship with the spectator that invites him or her to perform in response to the photograph" $(2013,137)$. Both Madison and Chambers-Letson gesture towards Roland Barthes's punctum, "the element that rises from the scene, shoots out of it like an arrow, and pierces [the spectator]" $(1981,26)$. In the Depression Era images I discuss here spectators encounter scenes from the economic crisis that explore non-linear notions of time. These images offer to audiences momentary experiences of detachment from capitalist temporality by critiquing future-oriented notions of progress, insisting on the cyclicality of crisis in capitalism, or refusing a narrative of causality altogether. Together they reveal an epochal sense of failure attached to capitalist teleology that is a quintessential affect of the Greek economic crisis.

\section{Landscapes of Crisis}

In one of the pictures from his series Nea Helvetia, Pavlos Fysakis captures a waste ground on the outskirts of the city. Piles of discarded plastic and glass bottles, aluminum cans, and shopping bags cover the soil, extending into the horizon. Their original colors have faded into a palette of grey and ochre, the indefinite color of decomposing trash. Nothing seems to grow on this soil, with the exception of a few scattered twigs barely standing among the piles of waste. The air is charged and polluted. 


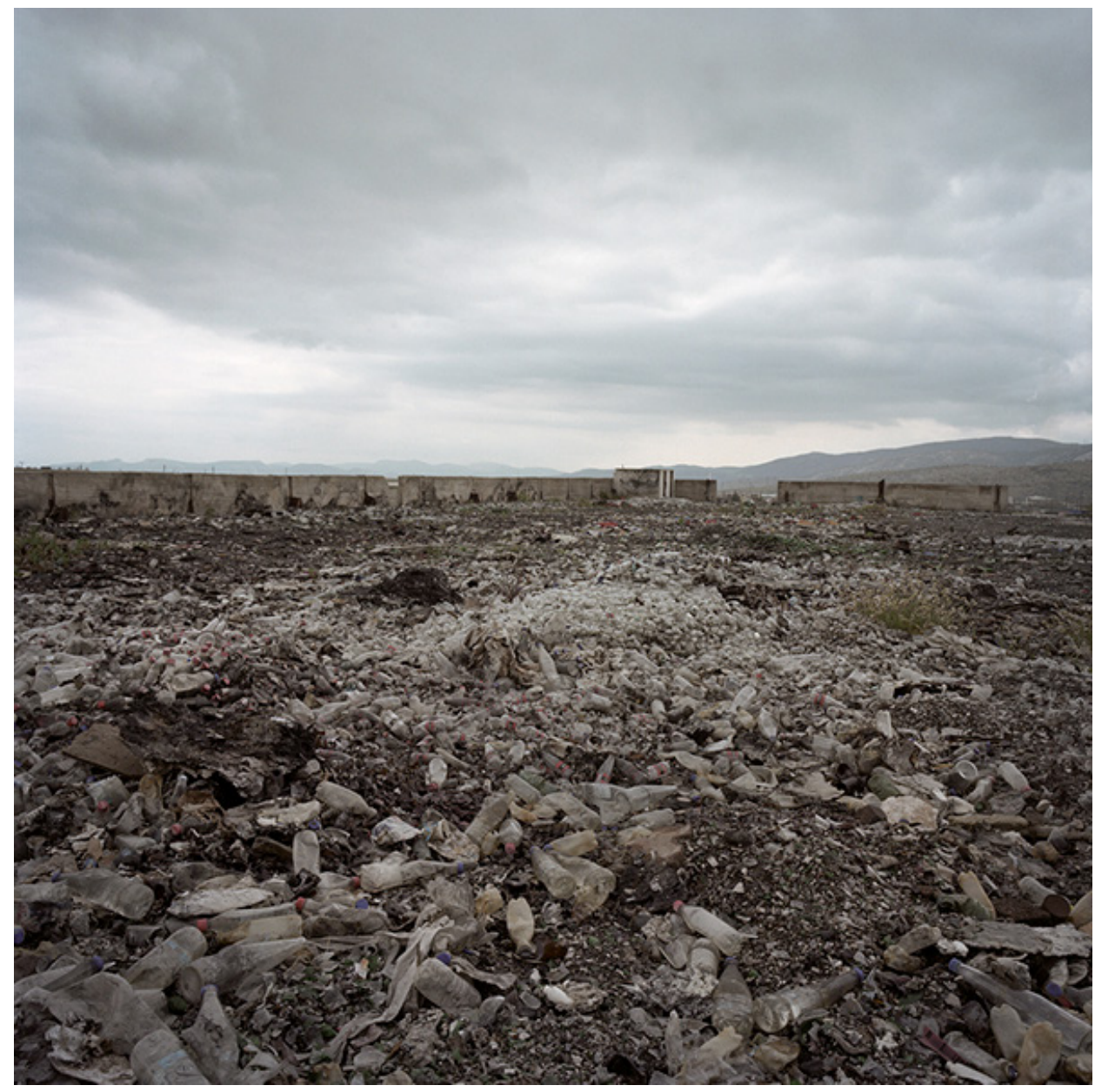

Image 1: Pavlos Fysakis. Dump, Aspropirgos. From Nea Helvetia, 2011.

Nea Helvetia (Image 1) is the name of a working-class area in the periphery of Athens that in Greek means "New Switzerland." Traditionally populated by industrial workers, Nea Helvetia was struck by poverty and unemployment before the beginning of the 2008 economic crisis, but its situation has rapidly deteriorated in the years of austerity. The name "New Switzerland" becomes a form of cruel irony in the series. In the European imaginary, Switzerland is a neoliberal utopia of efficiency, with ever-mobile flows of financial capital, millionaire banking operations, ironclad safes, and expensive watches that measure time with utmost precision. In the European South, Switzerland is also the place where national elites and politicians keep succulent bank accounts beyond the reach of national taxation laws. The promise of the infinite mobility of financial capital that Switzerland represents stands in contrast with the limited mobility of the people who live in "New Switzerland." In the series, Fysakis conveys the slow unbearable passing of days for jobless people who have no money to pay for gas or a ticket to ride the bus out of the neighborhood. Life in Nea Helvetia seems to have stopped with the economic crisis. 
The photo disrupts a capitalist understanding of time as progress through the depiction of waste generated from unsustainable modes of production/consumption. Dwelling in the presence of material waste that capitalism constantly creates but strives to make invisible, this image is a meditation on what the new always brings back, or to put it differently, of the continuous piling up of discarded newness and its potentially catastrophic consequences. The composition, with its horizontal symmetry between land and sky, and the wide angle of the camera cites landscape photography. However, instead of reveling in majestic views of nature, the image disrupts this genre by portraying a dystopian polluted environment. This is a landscape resulting from human activity and yet completely inhospitable to humans--a result of human actions whose consequences are no longer under human control.

Capitalism infuses the new with desirability, making commodities into the "sensuous things that are at the same time suprasensuous or social" (Marx [1867] 1990, 165). As a result, capitalism cannot escape generating ever-growing amounts of waste in its process of reproduction, because it is the pulse to create commodities that drives production and not the imperative to satisfy real needs (Marx [1857] 2010, 28). Making the new a value in itself is essential for our notion of modernity, which as Nancy has argued is "conceived as an incessant 'before,' as the time that precedes itself, that anticipates its future" $(2015,15)$. When we apprehend time as an incessant before, we need the constant production of the new as self-fulfilling prophecy of our history. Capitalist time is the time of compulsive newness. But of course, an economic system based on the compulsive production of the new conceals that it actually has no place for all that it produces. The production of the new thus runs parallel with the pilling up of everything that is discarded as soon as it ceases to be new. Or to put it differently, the production of the new is the production of waste, of that for which we have no use. Capitalism is the production of waste, mediated and realized through consumption. Not surprisingly, Benjamin's "angel of history" is irresistibly propelled to the future "while the pile of debris before him grows skyward" ([1940] 2007, 258).

As much as capitalism would have us believe that inanimate things disappear when we stop using them, they stay with us forever in some form or other, entering ecosystems and eventually transforming the bodies they come in contact with (Bennett 2010). Matter refuses to be contained in a linear narrative of progress, according to which what we produce can simply be left behind. It is against that idea of disappearance that Fysakis' picture works, as we are reminded that what was once new is constantly pilling up around us. Plastic containers, cans, bags, bottles--things no longer useful--have a life well beyond the use that we give them. As they are discarded and left to decompose, they seep into ecosystems and return to our bodies in various forms. The new accumulates to become catastrophic. "New Switzerland" also invokes an old colonial practice of naming new places after existing ones, hiding dispossession and destruction under the label of creation. But whereas the new of colonial naming disguised dispossession and genocide of the colonized under the promise of wealth for the colonizer, the new in the photographic series of New Switzerland is a refusal of this disguising practice. Here, the new is equated with the failure of all promises, with land and nature pollution, with lost unoccupied people that wander seamlessly in the landscapes. The picture demystifies the desirability of the new not as a nostalgic turn to the 
past, or a romantic look upon some golden time previous to the economic crisis, but as a rejection of capitalist notions of the future as endless growth.

Pavlos Fysakis' pessimistic take on capitalist progress is also shared by Marinos Tsagkarakis. Both authors frame their work as depicting the present of the economic crisis, but their images could certainly be read as playfully conveying post-apocalyptic tones, as if inviting their spectators to look upon the ruins of an entire way of life that has been abruptly interrupted. In one of his images (Image 2), Tsagkarakis depicts a winter day in a Cretan village, one of those uncountable places overdeveloped in the last decades of the twentieth century for the tourists that take over the Greek islands during high season. Empty, abandoned, or decaying tourist destinations are a recurring theme in Tsagkarakis' work. The photographer invites the spectator's gaze to roam around these places like it would on old theatre sets, framing commercial decay in ways that denaturalizes it and invests it with a spectacular quality. In his series Paradise Inn, the architecture of places made entirely for peoples' leisure does not only become strange when completely empty, but also affectively charged with haunting absence. Where did everyone go? What happened to them?

Without people, the promise of vacational enjoyment vanishes, leaving us with a place that looks cheap and unexceptional. If material surfaces communicate, the plastic, wood, and plaster in these

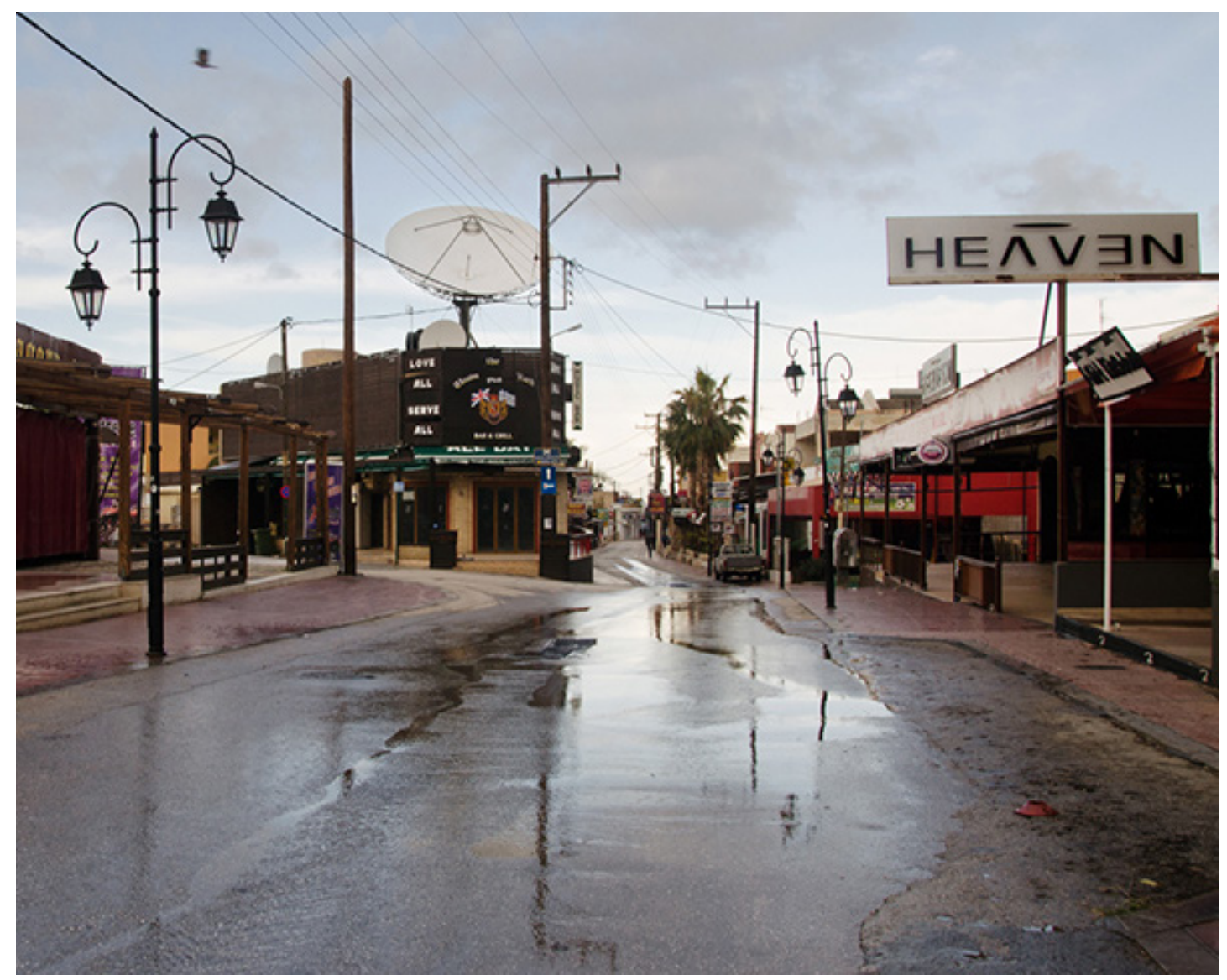

Image 2: Marinos Tsagkarakis. Heaven Can Wait. From Paradise Inn, 2013. 
buildings tell stories of rapid development seeking to turn a quick profit out of the tourist flow. It is unclear in the picture whether the tourists are supposed to arrive again with good weather, or if we are looking at a place that has been permanently left behind by the industry. This ambiguity, however, does not diminish the picture's affective force. Whether in between seasons or at the end of a larger economic cycle, it is the future promise of wealth that the picture reveals bankrupt. Tsagkarakis' body of work depicts economic and environmental decay as the result of capitalist development. In his pictures, random material remains appear left over from economic processes that have finished, leaving behind a geography of uselessness, of places that cannot be used for that which they were once created, but that cannot return either to the state in which they were before their development.

The photographic composition allows us to recognize and name specific forms of economic destruction. The effect of making strange everyday economic decay is heightened in the picture through the inclusion of the "heaven" sign, which works as an ironic punctum. The composition of the frame, with the "heaven" sign placed on the top right recalls road signs, such as those that we would see from the car during a road trip. Thus, heaven is not just the name of the dance club, but also a sarcastic brand of the whole setting. The composition suggests that we are entering a place called "heaven," although "heaven" is just an empty, rainy, abandoned street intersection in a vacation village during wintertime. Our attention is captured by this formal juxtaposition of the banality of the scene and the connotations that the notion of heaven conjures up to immediately disavow.

"Heaven" also playfully gestures towards the notion of time that capitalism borrowed as a secular version of Christian teleology. As Giorgio Agamben has pointed out, the capitalist version of this teleology is "sundered from any notion of end," which makes progress infinite $(1993,96)$. Both versions of this teleology, Christian and secular, are predicated on future fulfillment that rewards only those whose present behavior suits the precepts of a higher power--the precepts of Christian morale, or those of the free market, respectively. As heaven awaits for good Christians, so does wealth awaits for those who have been diligent laborers within the system of production. Both are also predicated on a future promise. Neoliberal discourses about austerity are evidence of this, promising future bliss (economic growth) in exchange for present sacrifice. But the temporality of the promise is one of endless deferral, or as Lauren Berlant has argued, of "cruel optimism" (2011). "Cruel optimism" is a set of affective attachments through which subjects in neoliberal economy hope for future material fulfillment, and it is precisely this future-oriented promise what allows for the endurance of oppressive conditions in the present.

It was Walter Benjamin ([1921] 1999) who argued that "capitalism is a pure religious cult, perhaps the most extreme there ever was" (259). Benjamin stresses the cult's "permanent duration," the fact that capitalism structures the entirety of time according to its own rules, so that even time that is not directly dedicated to labor is still seeped into capitalist temporal arrangements. If this was true for Western societies in Benjamin's time, when Fordism was the central model of production driving accumulation, the current conjuncture of financial global capitalism has only exacerbated this tendency, collapsing the differences between work and rest time to generate profit from 
activities that are not always identifiable as labor. Under neoliberalism, Benjamin's concern that capitalism's temporality is that of a religious cult that structures the entirety of life have become all the more pertinent.

Tsagkarakis' image of the demise of a holiday spot evokes this similitude between Christian and capitalist teleology from an ironic perspective. He cites the Christian notion of "heaven" only to playfully disavow the transcendence of material life that heaven is associated with. Instead of transcendence, the image anchors heaven to a place in which economic and material constraints cannot be easily transcended, neither by a local population whose livelihood might depend on or be greatly affected by the tourist industry, or by visitors who are ultimately confronted with the banality of flashy business fronts that they could encounter anywhere else. Looking at these images, one almost becomes a future observer who dwells with archeological curiosity upon the ruins of bars, hotels, and dance halls and speculates about the civilization that inhabited them. Tsagkarakis' work resembles Fysakis' in that both seem to offer to their viewers the possibility to momentarily inhabit a post-capitalist future, a place from which to look behind at the havoc created by contemporary capitalism. Once a place is ecologically destroyed, once an economic cycle ends, once livelihoods have been compromised, once money can no longer be made, what comes next?

Whereas Fysakis' and Tsagkarakis' work disrupt the linearity of capitalist time by gesturing towards catastrophic futures, George Salameh's work dwells on the duration of crisis to question neoliberal discourses that present it as an isolated accident in a temporality of endless growth. In one of his photographs (Image 3), we contemplate a moment in the unfolding of a quotidian street scene. A man in white shirt, blue pants, and blue cap sweeps the sidewalk. To his left, an old white car is parked under in the shade of a tree; to his right, a black car. Three other trees with abundant bright green foliage indicate it is spring, perhaps summer. On the left side of the sidewalk, a woman dressed in dark colors is walking out of the frame, possibly running errands. Our attention barely brushes through this quotidian scene on the sidewalk before moving to the background. There, an immense partially torn canvas features a panoramic view of the Acropolis. Through the tear, we see the decrepit condition of the building underneath.

Although Salameh contributed this picture to Depression Era, he took it a few years earlier, around 2004. At that time, the city administration undertook massive political economic transformations to host the 2004 Olympic Games. These transformations involved real estate operations benefiting private interests over public ones, and the effort to cover those parts of the city deemed unsuited for the gaze of the Olympic Committee, international spectators, and expected tourists (Boycoff 2014). By covering certain buildings with large canvases, the Olympic audience would get a carefully curated version of Athens as the archeological treasure that appears in travel guides and postcards, avoiding the reality of housing conditions for the poor. Presumably accidental, the tear in the canvas attracts and captures our attention in this photograph. The tear does not only reveal what was supposed to remain hidden, but it also makes visible the politics of masking reality undertaken by the city administration. 


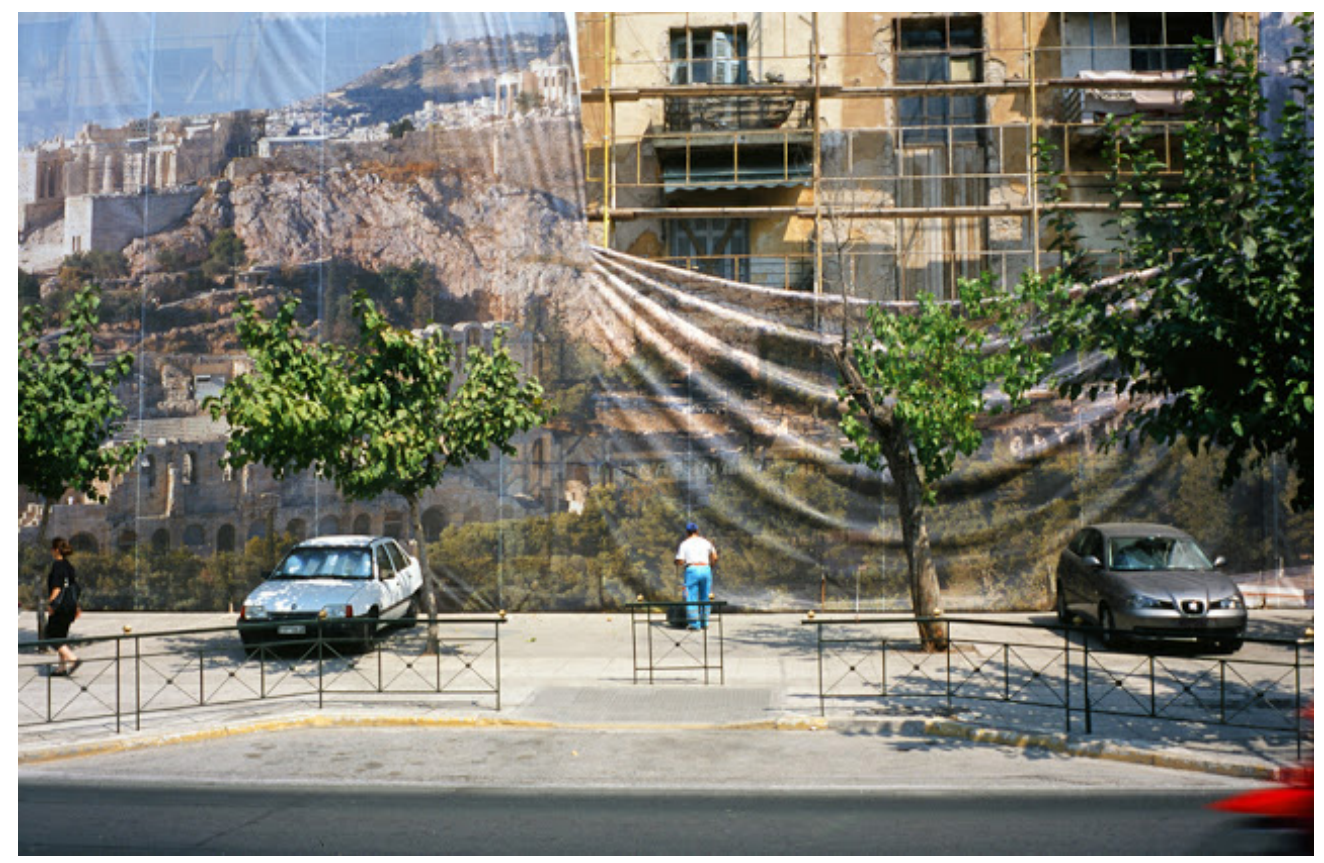

Image 3: Georges Salameh. Sweeper. From Spleen, 2004.

The building belongs to the Kountouriotika complex on Alexandras Avenue, a group of eight apartment buildings erected in the 1930s to host the refugees from the Greco-Turkish war of 1922. ${ }^{2}$ At the time of the picture, the complex had been in a ruinous state for years. The city's plan was to demolish it and sell the land to private development in order to build a mall, but popular resistance forced it to declare the Kountouriotika buildings a protected site of historical relevance. In the years since the eruption of the economic crisis and as of this writing, the buildings have been occupied by low income and homeless people.

In the foot accompanying the photograph, Salameh explains his choice to include in Depression Era an image that he took in 2004 in terms of the image's ability to act as a "premonition of a new era for Athens." Salameh thus points out that Greek economic policies in the early 2000s were already signaling larger neoliberal trends of disassembling of state social services in favor of private capital, a trend that has surely worsened in the aftermath of the economic crisis, but that the crisis did not initiate. By foregrounding the divinatory nature of the image, the photographer makes a political economic commentary on the contemporary moment, while stating his aesthetic engagement with temporal tropes of repetition and cyclicality. The trope of premonition, of the image's ability to reveal the economic future, is essential to how the image performs for the spectator, taking several meanings. First, in the most literal sense, the photograph makes visible what is underneath the canvas, the ruinous façade that would otherwise remain hidden. Second, it reveals the official attempts to hide poverty during the celebration of the Olympics. Third, in the photographer's words, it reveals a future time of economic crisis, which has not happened yet when the image was taken in 2004. The photographer makes the image perform several distinct moments in time that refuse linearity and that he presents instead as overlapping, collapsing onto 
each other. These moments reveal a recurrence, a cyclicality of crisis that is inherent to the normal functioning of capitalism.

Salameh's image counters narratives of the economic crisis as an accident provoked by a malfunctioning of financial markets, depicting it instead as inherent to capitalism. In his photo, poverty and urban destruction are part of the everyday. The desolation of the building underneath the canvas does not reach the category of something eventful or catastrophic, but rather ordinary. He depicts what Elisabeth Povinelli has defined as "economies of abandonment," entire geographies left behind because they are deemed unproductive by capital, and social groups whose material life conditions slowly but surely erode their ability to endure and survive (Povinelli 2011). Salameh's picture demonstrates that crisis is part of economies of abandonment, a letting die that is essential to the functioning of neoliberalism. Despite official EU discourses casting the crisis as an accident that can be overcome through sacrifice, the reality of the crisis is that of slow erosion, the perpetuation of dispossession as the normal functioning of the economy. The discourse of crisis as an event, however, is essential to justify austerity, because it holds the promise of an economic cure that is attainable though budget cuts, restrained public spending, and dismantling of state social protections. Salameh's image insists in excavating the connections between present and past moments, drawing their similarities, refusing the discourse that presents crisis as an isolated event instead of neoliberalism as usual.

In the last picture (Image 4), we see the base and the lower part of a white marble column, part of a white marble tiled floor, and in the background, a white surveillance camera that stands out against the dark red wall. This is a picture of the entrance of the Archaeological Museum in Athens, part of Yiannis Hadjiaslanis' series After Dark. In this series, Hadjiaslanis shot Athens' centre at night, during the weeks following an intense period of riots in February 2012. These riots, the most violent ones in the city since those following the murder of 14-year old Alexandros Grigoropoulos by police in December of 2008, coincided with the negotiations of the Second Memorandum to the Greek economy between the Troika ${ }^{3}$ and the national government. During the riots,

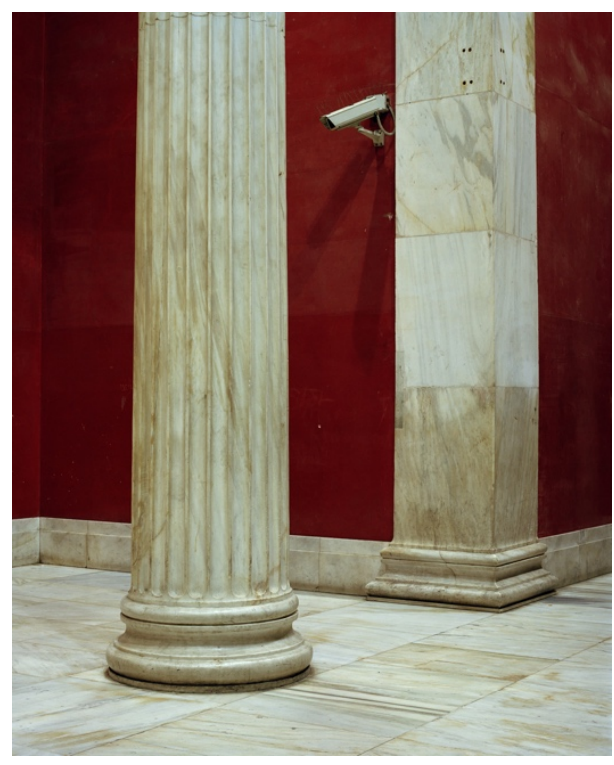

Image 4: Yiannis Hadjiaslanis. Mouseio II. From After Dark, 2012. many buildings in the city centre were set on fire, eliciting rumors whether the perpetrators of all the fires were indeed anarchists, as the media and political establishment argued, or if groups affiliated with fascist party Golden Dawn were also responsible. The period of negotiations and the ensuing riots marked a moment of political contingency, a heightened intensity in the life of the nation in which radical political change seemed possible. 
Although the shooting of After Dark coincides with a moment of urban upheaval, in this series Hadjiaslanis purposefully dwells on settings that seem solitary and quiet. In intimate proximity with the objects he shoots, Hadjiaslanis uses close ups rather than the wide shots that these settings usually call for. In this way, he calls attention to the details of the settings, the textures of the architectural surfaces, the traces of human activity, the materials, almost as if he were collecting the evidence of a social cataclysm so he could order it into a logical narrative at a later date. These compositional choices are essential to the stillness that Hadjiaslanis depicts and that we can understand as a photographic documentation of a halt in homogeneous empty time, a historical moment of contingency in Greek political and public life.

Throughout the history of Western civilization, white columns--of marble or other materials-seem to have been a preferred architectural staple to mark the places where power, in its diverse secular or religious forms, holds its ground in spectacular, monumental ways. From the Athenian Parthenon to the Washington Capitol Building, white columns are an element of institutional staging, a performative device through which existing power evokes authority, permanence, and historical legitimacy. In Hadjiaslanis' image, the white marble column thematically cites these tropes of monumentality, but the composition disavows them. Stripped to their bare bones, the camera and the marble column become the central elements. Through this juxtaposition of a monumental setting with a composition that undermines monumentality and foregrounds panoptical ${ }^{4}$ economies of surveillance, the photograph represents neoliberal biopower at a time when the Greek economic crisis seemed to have reached its climax.

In the period of 2011-2012, the Archaeological Museum and the surrounding area were part of an urban vortex of rioting and street battles. A neo-classical building on Patission Street, the Museum sits right next to the Polytechnic University, where the social movement that overthrew the Junta dictatorship started in the 1970s, and which has been ever since a central location in the local geography of Athenian leftist radical movements. The same can be said of the adjacent streets of Exarcheia, the neighborhood where 14-year-old Alexis Grigoropoulos was killed by police, and where the riots motivated by his death started and spread out from in December 2008. Each year, Exarcheia's anarchists commemorate Alexis' death by engaging the police in a street fight that takes place steps away from the Museum. In the surrounding streets, cars and dumpsters are set on fire, and the explosions of homemade Molotov cocktails and responding police tear gas last from sunset until dawn. After the 2008 riots and until the 2015 election of Syriza, Exarcheia was permanently under siege by anti-riot police units, which were daily camped in the streets leading to the neighborhood, stopping pedestrians, requesting identifications, and conducting searches. Since the eruption of the economic crisis, the Museum entrance, its garden, and the surrounding area have also become a hangout spot for homeless heroin addicts, an ever-growing group that cannot count anymore on structures of public assistance eliminated by austerity.

Although it might seem like a casual setting, as an urban location affected by drastic social changes, political violence, and the presence of vulnerable social groups, the entrance of the Archaeological Museum is politically charged. Looking at the image from a historical materialist perspective that excavates this political charge, we can find in the picture the signs of what Benjamin calls 
"revolutionary time." For Benjamin, revolutionary time animates struggles of the past beyond just tracing their causal relation to the present. A historical materialist "approaches a historical subject only where he encounters it as a monad. In this structure he recognizes the sign of a Messianic cessation of happening, or, put differently, a revolutionary chance in the fight for the oppressed past" ([1940] 2007, 263). Underneath what might look at first sight as a casual reference to archeological treasures, the picture contains references to recent episodes of Greek history. Hadjiaslanis' picture works against the relationship of causality that underscores narratives of historical progress, suggesting that there's much more to history that the eye can see, or that official narratives recount. He presents us with an intentional incompleteness that we confront but that we cannot easily resolve. To some extent, the picture is obfuscating, refusing any narrative of causality. Without the frame of causation, we are just left contemplating a historical object placed out of linear time. And yet, the setting captured in the picture is a place in which different but interlocking processes related to the contemporary immiseration of Greek urban life unfold. It is a document of history that refuses progress and instead looks for a deeper form of engagement with past, present, and future.

\section{Afterword: Afterward}

At the end of his reflections on catastrophes, Jean Luc Nancy speculates that our way out of impending doom demands a different conception of time, one that does not rush towards the future but instead appreciates the fullness of the present. This is not a present in which we know of the coming catastrophes but pretend to ignore them through immediate hedonistic gratification, but a present of making things anew $(2015,38)$. It is a process of creating material conditions that are not hijacked by capitalist notions of progress and growth and their disastrous environmental and social consequences. Although speculative and abstract, Nancy's notion of the present is also intriguing, posing important questions: If our hegemonic notion of time is that of linear progress, if our modes of organizing politically, economically, and socially are compulsively teleological, how can we even start imagining time differently?

Given the essential relationship of photography and time, the realm of the visual might be a starting place to imagine temporalities that are not compromised by catastrophic capitalist futures. In Depression Era's work, we are offered a variety of performative encounters with time, whether we are taken to post-apocalyptic landscapes that are at once our present and our future, prompted to look ironically at promises of future wealth, allowed to reflect on the cyclicality of what always comes back or perhaps never leaves, or refused the recourse of causality to explain our historical present. Shooting the Greek economic crisis, the Depression Era photographers that I have examined in this essay force us to look at the failure of our present modes of social organization. We are momentarily confronted with palpable catastrophe and made to wonder: What now? Instead of answers, we are invited to dwell in the question. And the place of the question, the place from which all that is left to us is to gaze on the emptiness of our notion of progress might constitute the very place where we finally let go of our attachment to it. 
1 Throughout this essay, I use the terms capitalism and neoliberalism to talk about similar yet different phenomena. I understand neoliberalism to be a phase in the development of capitalism (Harvey 2005), and yet also a qualitatively different form of organizing the economy and social life more broadly. In neoliberalism, not only does financial capital become the engine of economy in substitution of industrial production (Hardt and Negri 2005), but we also see an increasing decoupling between finance and production (Marazzi 2011), and the subjugation and management of populations through debt (Lazzarato 2012). Moreover, neoliberalism is also a form of governance in which economic growth is the end legitimation of government. This mode of governance evacuates democratic principles from the political to order all spheres of life according to the market (Brown 2015). Crucial to this form of governance, neoliberalism shapes the formation of the self, subjecting individuals to a perpetual sense of precarity (Lorey 2015), as well as expectations to constantly improve the self to adapt to the market and achieve beyond the limits of exhaustion (Chul Han 2015).

2 At the end of the First World War and as part of the process of dismantling the former Ottoman Empire, Western Allies supported Greece's war against Turkey. The nationalist plan of the Greek state was to claim territories in Asia Minor that were under Greek influence during the ancient period but that had become part of the Ottoman Empire. In 1922, after three years of civilian massacres on both sides, the two countries reached an agreement involving a major displace of population. Turkey sent to Greece about one million Greek Orthodox Christians who had been living on Turkish territory; in exchange, Greece reciprocated with half a million Muslims who had been living on Greek territory.

3 IMF, European Central Bank, and European Commission.

${ }^{4}$ My use of panoptical derives from Michel Foucault's definition of "panopticon" in Discipline and Punish (1977).

\section{Works Cited}

Agamben, Giorgio. 1993. Infancy and History: The Destruction of Experience. New York: Verso.

Barthes, Roland. 1981. Camera Lucida: Reflections on Photography. New York: Hill and Wang.

Bennett, Jane. 2010. Vibrant Matter: A Political Ecology of Things. Durham, NC: Duke University Press.

Benjamin, Walter. (1940) 2007. "Theses on the Philosophy of History." In I/luminations: Essays and Reflections. Edited by Hannah Arendt, 253-264. New York: Schocken.

___. (1921) 1999. "Capitalism as Religion." In Selected Writings Volume I, 1911-1926. Edited by Marcus Bullock and Michael W. Jennings, 259-262. Cambridge, MA: Belknap.

Berlant, Lauren. 2011. Cruel Optimism. Durham, NC: Duke University Press. https://doi.org/10.1215/9780822394716

Boycoff, Jules. 2014. Celebration Capitalism and the Olympic Games. Oxford and New York: Routledge.

Brown, Wendy. 2015. Undoing the Demos: Neoliberalism's Stealth Revolution. New York: Zone.

Chambers-Letson, Joshua. 2013. A Race so Different: Performance and Law in Asian America. New York: New York University Press. https://doi.org/10.18574/nyu/9780814738399.001.0001

Foucault, Michel. 1977. Discipline and Punish: The Birth of the Prison. New York: Pantheon.

Hamera, Judith. 2017. Unfinished Business: Michael Jackson, Detroit, and the Figural Economy of American Deindustrialization. New York: Oxford University Press. https://doi.org/10.1093/oso/9780199348589.001.0001

Han, Byung-Chul. 2015. The Burnout Society. Stanford, CA: Stanford University Press. 
Hardt, Michael, and Antonio Negri. 2005. Multitude: War and Democracy in the Age of Empire. New York: Penguin.

Harvey, David. 2005. A Brief History of Neoliberalism. Oxford: Oxford University Press.

Karatani, Kojin. 2003. Transcritique: On Kant and Marx. Cambridge, MA: MIT Press.

Lazzarato, Maurizio. 2012. The Making of the Indebted Man. Los Angeles, CA: Semiotext(e).

Lorey, Isabell. 2015. State of Insecurity: Government of the Precarious. New York: Verso.

Madison, D. Soyini. 2013. "Dressing Out-of-Place: From Ghana to Obama Commemorative Cloth on the American Red Carpet." In African Dress: Fashion, Agency, Performance. Edited by Karen Tranberg Hansen and D. Soyini Madison, 217-230. New York: Bloomsbury.

Marazzi, Christian. 2011. The Violence of Financial Capital. Los Angeles, CA: Semiotext(e).

Marx, Karl. (1867) 1990. Capital. Volume I. New York: Penguin.

. (1857) 2010. "Introduction". In Marx \& Engels: Collected Works, Volume 28 [The Grundrisse], 17-48. London: Lawrence \& Wishart.

Nancy, Jean-Luc. 2015. After Fukushima: The Equivalence of Catastrophes. New York: Fordham University Press.

Negri, Antonio. Time for Revolution. 2003. London and New York: Bloomsbury.

Povinelli, Elisabeth. 2011. Economies of Abandonment: Social Belonging and Endurance in Late Liberalism. Durham, NC: Duke University Press. https://doi.org/10.1215/9780822394570

Williams, Raymond. 1977. Marxism and Literature. Oxford and New York: Oxford University Press.

Wynter, Sylvia. 1996. "Is Development a Purely Empirical Concept, or also Teleological?: A Perspective from 'We the Underdeveloped."' In Prospects for Recovery and Sustainable Development in Africa. Edited by Aguibou Y. Yansané, 299-316. Westport, CT: Greenwood.

2003. "Unsettling the Coloniality of Being/Power/Truth/Freedom: Towards the Human, after Man: Its Overrepresentation-An Argument." New Centennial Review 3 (3): 257-337.

https://doi.org/10.1353/ncr.2004.0015

\section{Biography}

Andreea S. Micu is a PhD candidate in the Department of Performance Studies at Northwestern University, and a Public Humanities Fellow at the Chicago Humanities Festival. Her research examines the intersection of performance, aesthetics, and contemporary anti-austerity activism in the South of Europe in the aftermath of the 2008 European economic crisis. Her dissertation, Performing the Commons: Urban Aesthetics in the Aftermath of the Southern European Economic Crisis looks at how urban working classes use performance and aesthetic production to imagine alternatives to neoliberalism and (re)build the urban commons in Madrid, Rome, and Athens, where she has conducted extended ethnographic research. Andreea's research interests more broadly include Marxist feminism, performance art, political philosophy, affect theory, critical urban studies, and performance pedagogy.

(C) 2018 Andreea S. Micu

Except where otherwise noted, this work is licensed under a Creative Commons Attribution-

NonCommercial-ShareAlike 4.0 International License. 